\title{
Factors influencing small, medium and micro-sized enterprises' borrowing from banks: The case of the Botswana manufacturing sector
}

\begin{tabular}{|c|c|}
\hline \multicolumn{2}{|c|}{$\begin{array}{l}\text { Authors: } \\
\text { Wilbert R. Mutoko }{ }^{1} \\
\text { Stephen M. Kapunda }\end{array}$} \\
\hline \multicolumn{2}{|c|}{$\begin{array}{l}\text { Affiliations: } \\
{ }^{1} \text { Graduate School of Business } \\
\text { and Government Leadership, } \\
\text { North-West University, } \\
\text { South Africa }\end{array}$} \\
\hline \multicolumn{2}{|c|}{$\begin{array}{l}{ }^{2} \text { Department of Economics, } \\
\text { University of Botswana, } \\
\text { South Africa }\end{array}$} \\
\hline \multicolumn{2}{|c|}{$\begin{array}{l}\text { Corresponding author: } \\
\text { Wilbert Mutoko, } \\
\text { wilbertmutoko@gmail.com }\end{array}$} \\
\hline \multicolumn{2}{|c|}{$\begin{array}{l}\text { Dates: } \\
\text { Received: } 13 \text { July } 2016 \\
\text { Accepted: } 21 \text { Jan. } 2017 \\
\text { Published: } 31 \text { May } 2017\end{array}$} \\
\hline \multicolumn{2}{|c|}{$\begin{array}{l}\text { How to cite this article: } \\
\text { Mutoko, W.R. \& Kapunda, } \\
\text { S.M., 2017, 'Factors } \\
\text { influencing small, medium } \\
\text { and micro-sized enterprises' } \\
\text { borrowing from banks: The } \\
\text { case of the Botswana } \\
\text { manufacturing sector', Acta } \\
\text { Commercii } 17(1), \text { a } 426 \text {. } \\
\text { https://doi.org/10.4102/ } \\
\text { ac.v17i1.426 }\end{array}$} \\
\hline \multicolumn{2}{|c|}{$\begin{array}{l}\text { Copyright: } \\
\text { (C) 2017. The Authors. } \\
\text { Licensee: AOSIS. This wC } \\
\text { is licensed under the } \\
\text { Creative Commons } \\
\text { Attribution License. }\end{array}$} \\
\hline \multicolumn{2}{|c|}{ Read online: } \\
\hline 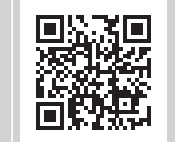 & $\begin{array}{l}\text { Scan this QR } \\
\text { code with your } \\
\text { smart phone or } \\
\text { mobile device } \\
\text { to read online. }\end{array}$ \\
\hline
\end{tabular}

The objective of the study: The main objective of this study is to determine the factors that influence manufacturing small, medium and micro-sized enterprises' (SMMEs) borrowing from banks.

Problem statement: This article examines factors that affect SMMEs' ability to borrow money from commercial banks. Empirical evidence was collected from manufacturing SMMEs.

Motivation for the study: There is a scarcity of studies on factors influencing borrowing among Botswana manufacturing SMMEs.

Methodology: The study employed both qualitative and quantitative research designs. The random stratified sampling technique was used to draw a sample of 100 manufacturing SMMEs from a population of 329 registered manufacturing SMMEs in Botswana. Descriptive and inferential statistics were used to analyse the data. Furthermore, multivariate logistic regression estimation was used to obtain the main objective.

Main findings: The empirical results showed that longevity in position and annual turnover have positive impact on getting access to bank loans, while marital status has a negative effect on access to bank loans.

Practical implications: An understanding of factors influencing borrowing can increase chances of an SMME gaining financing from commercial banks, thus solving the challenge of access to finance.

Contributions: The results are significant to SMMEs, policymakers, the banking sector and other researchers. Furthermore, this study increases literature on SMME challenges and financing logistics.

\section{Introduction}

Botswana's economy is largely dependent on revenue from the mining sector, especially diamond mining. Remarkably, through prudent resource management, government has become the most important and the biggest player in the economy (Jefferis 2014; Mutoko, Mokone \& Thindwa 2015). The government sector, that is, the public sector, is the major employer and facilitator in the economy. Hence, the private sector largely depends on the public sector for its survival. This type of relationship is not healthy in the long run. Recognition of the negative effect of dependency syndrome and of the unsustainability of diamond revenue in the long run has resulted in a quest for economic diversification. One of the economy diversification drives is to support sustainable growth of small, medium and micro-sized enterprises (SMMEs).

The manufacturing sector has been identified as one for possible diversification. In Botswana, evidence has shown that over the years manufacturing has been on the decline, hence, there is need to discover ways to resuscitate the sector (Botswana Central Statistics Office 2015; Hillbom 2012; Sekwati 2010:80). To resuscitate the manufacturing sector, there is therefore a need to understand financing challenges, which have been highlighted by literature as the major concern for SMMEs, and to know how to deal with them. The financing challenges are rooted partly in the factors that influence SMME borrowing.

Some authors argue that SMMEs are the backbone of the majority of the world's economies (Messah \& Wangai 2011; Rhodes 2012). However, adequate financing has been a major factor hindering SMME success. Okurut, Olalekan and Mangadi (2011) argue that 'historically, the 
TABLE 1: Definitions of small, medium and micro-sized enterprises in Botswana.

\begin{tabular}{llll}
\hline Variable & Micro enterprises & Small enterprises & Medium enterprises \\
\hline $\begin{array}{l}\text { Number of employees } \\
\text { Sales turnover per annum }\end{array}$ & Six or fewer employees & Less than 25 employees & Between 25 and 100 employees \\
& & $\begin{array}{l}\text { Between P60 000 and P1 500 000 (USD5386 } \\
\text { and USD134 661) }\end{array}$ & $\begin{array}{l}\text { Between P1.5 million and P5 million (USD134 661 } \\
\text { and USD448 870) }\end{array}$ \\
\hline
\end{tabular}

Source: Republic of Botswana, 2010

formal credit market in Botswana has been dominated by commercial banks, which are the major suppliers of credit to households and private businesses'. While there are a number of ways to finance individuals and organisations, commercial banks have always been expected to play a major role in financing individuals and SMMEs alike. In Botswana, the 1998 taskforce distinguished SMME as in Table 1.

\section{Challenges of small, medium and micro-sized enterprises}

There is been an ongoing debate on SMME development and their contribution to Botswana's economy (Baliyan 2013; Mutoko 2014). The debate focuses on SMMEs' role in employment creation, poverty eradication, GDP contribution and economic diversification (Baliyan 2013; BIDPA 2009; Jefferis 2014). Wiklund and Shepherd (2005) argue that small firms dominate world economies and also that they are a source of livelihood and employment for many. Their growth and sustainability is crucial, and especially for SMMEs in the manufacturing sector. Jefferis (2014) and Moore et al. (2010) say that, although manufacturing SMMEs have the potential to create long-term employment, there are some challenges that threaten their survival and growth. These challenges include access to markets, financial challenges, lack of business acumen, poor or no recordkeeping on business performance, poor quality products and lack of competitiveness.

In addition, Haron et al. (2013) adds that lack of funding, lack of expertise, lack of innovation, no or poor planning and poor management are some of the challenges manufacturing SMMEs face. Many other authors, including the authors of this article, have repeatedly mentioned the above challenges as being pertinent to manufacturing SMMEs (Andrae \& Beckman 2013; Mutambi 2013; Okurut et al. 2011; Shemi 2013). Of all the challenges that manufacturing SMMEs face, lack of finance has been identified by this article and many others as the major challenge that hinders SMMEs from tapping into the available business opportunities (Table 2).

Table 2 shows some of the challenges that the manufacturing SMMEs face in Botswana. Of all the challenges that the manufacturing SMMEs identified, lack of financing was most cited and is the main factor that hinders SMME growth. SMMEs said there is a need for financing assistance. Numerous scholars agree that apart from governments providing SMME funding, commercial banks are the major financiers or potential financiers for SMMEs (Abdesamed \& Wahab 2014; Abor, Agbloyor \& Kuipo 2014; Gichuki, Njeru \& Tirimba 2014; Haron et al. 2013; Padilla-Perez \& Ontañon 2013; Senior 2012). Therefore, this study generally considers available financing options for SMMEs; but, based on views
TABLE 2: Challenges faced by small, medium and micro-sized enterprises in tapping into the available business opportunities.

\begin{tabular}{|c|c|c|}
\hline \multirow[t]{2}{*}{ Challenges } & \multirow{2}{*}{$\frac{\text { Multiple responses }}{N=63}$} & \multirow{2}{*}{$\begin{array}{c}\text { Percentage } \\
\text { of cases }\end{array}$} \\
\hline & & \\
\hline Lack of ethical employees & 1 & 1.6 \\
\hline High costs of production & 2 & 3.2 \\
\hline Scarcity of skilled manpower & 9 & 14.3 \\
\hline Inability to grow beyond local market & 2 & 3.2 \\
\hline Licensing & 1 & 1.6 \\
\hline Transport & 1 & 1.6 \\
\hline Market access & 4 & 6.3 \\
\hline Lack of finance & 23 & 36.5 \\
\hline Competition & 6 & 9.5 \\
\hline Lack of land & 4 & 6.3 \\
\hline Illegal businesses in manufacturing & 1 & 1.6 \\
\hline Importing equipment from outside the country & 1 & 1.6 \\
\hline Low phone network coverage and Internet & 2 & 3.2 \\
\hline Poor management handovers and high turnover & 1 & 1.6 \\
\hline No money in circulation in the economy & 1 & 1.6 \\
\hline Government policies & 1 & 1.6 \\
\hline Rejection of work permits by government & 1 & 1.6 \\
\hline Lack of business knowledge & 1 & 1.6 \\
\hline Lack of working capital and raw materials & 1 & 1.6 \\
\hline Corruption & 1 & 1.6 \\
\hline Late payments by customers and competition & 1 & 1.6 \\
\hline
\end{tabular}

Source: Research findings 2015.

$N$, number.

of the mentioned scholars, commercial banks are the major consideration for financing of manufacturing SMMEs in Botswana. This is because government has a limit in terms of financial support to manufacturing SMMEs.

Furthermore, in Botswana, there is a scarcity of literature on manufacturing SMMEs and especially on their financial challenges. It is not easy to get literature on SMMEs, let alone on the challenges of manufacturing SMMEs. This means that policymakers and academics cannot find adequate studies to draw knowledge from. Against the background of information asymmetry and for the sake of addressing the research gap, this article examined the factors that affect manufacturing SMMEs' ability to obtain bank loans. The rest of the article includes a review of the literature, methodology, findings and discussions, conclusion and implications.

\section{Literature review}

\section{Theoretical framework}

The theory most relevant to this article is the credit rationing theory, which was hypothesised by Stiglitz and Weiss (1981), advocating that asymmetric information (superior private information compared to what the other party knows) and agency problems (conflict between management and firm owners and shareholders) are the driving forces behind credit rationing behaviors of credit providers to SMMEs. Credit 
rationing is closely related to the financing gap, which refers to the difference between the demand for funds by SMMEs and the supply of funds (Mazanai \& Fatoki 2012).

In their argument, Stiglitz and Weiss (1981:393) ask the question 'why is credit rationed?' As they try to justify reasons for credit rationing, they say:

The bank is not able to control all the actions of the borrower; therefore, it will formulate the terms of the loan contract in a manner designed to induce the borrower to take actions which are in the interest of the bank, as well as to attract low-risk borrowers. (p. 394)

Therefore, credit rationing mainly happens because banks want to reduce risk. Risk is linked to information asymmetry. With information asymmetry, it can go either way: either the bank knows what borrowers do not know, or the borrower knows what the bank does not know. The party lacking information is at risk and suffers in decision-making.

In the relationship between banks and borrowers, information asymmetry leads to two major risks for the banks: moral hazard and adverse selection. Moral hazard, defined as a situation where the borrower knows their intentions, the borrower misuses the loan and most likely fails to pay back the loan (Ghimire \& Abo 2013; Huang, When \& Liu 2014:29; Mutoko et al. 2015). Adverse selection refers to a situation where information related to the borrower's credit, project risk and benefits are better known by borrowers than by financial institutions (Ghimire \& Abo 2013; Huang et al. 2014:29). To further the discussion, Ghimire and Abo (2013:33) argue that existence of information asymmetry between banks and potential SMME borrowers has severe implications on the banks' lending methods. To avoid effects of using imperfect client information, in the absence of insufficient financial information; banks over-rely on requesting high collateral values to reduce the risks associated with adverse selection and moral hazards. A good lender-borrower relationship can be a solution for information asymmetry. Thus, information asymmetry plays a huge role in the relationship between financial institutions and SMME borrowers.

Furthermore, the bank's credit rationing decision is influenced by factors related to borrowers' observable characteristics, such as age, gender, experience and credit history. It can also be influenced by firm characteristics (business experience, turnover and earnings) and loan characteristics (amount demanded, loan maturity, collateral offered and interest rate). The procedures that banks follow before giving loans to SMMEs include screening, evaluation and quantity rationing (Lapar \& Graham 1988; Nuryartono, Stefan \& Manfred 2005). In the screening stage, the borrower is interviewed by the banks to determine their creditworthiness. The officer in charge of the loan will look into the viability of the investment, the credit history, management of the venture and the value of the collateral. At the quantity stage, the loan officer will determine the optimal loan size for the borrowers, which is less than the borrower needs.

The firm's collateral influences the bank's willingness to lend. The higher the collateral, the more likely that the firm will get the loan and the reverse is also equally true. The collateral is a signal that banks use to determine a profitable project (Rothschild \& Stiglitz 1971). According to Bester (1987), collateral limits the borrower from indulging in a very risky venture and as such solves the problem of moral hazard. Also, credit rationing can be influenced by the retained earnings or internal financing of the firm.

According to pecking order theory, firms will only seek a bank loan if their internal financing is low or cannot meet the expected venture (Aabi, 2014; Myers 1984). Nevertheless, as the firm expands, the financial needs also change and the firm must decide the best way to meet these needs. Contrary to pecking order theory, the static trade-off theory stipulates that a firm might have sufficient retained earnings and yet decide to borrow from a bank. This theory argues that the firm borrows from banks in order to hedge against unseen circumstances, which is also based on the costs and benefits of debt finance (Harris \& Raviv 1990; Modigliani \& Miller 1963). In this article, credit rationing theory is adopted based on the nature of the manufacturing SMMEs in Botswana. This theory stipulates that bank loans to manufacturing SMMEs is a function of firm characteristics, observable characteristics and loan characteristics.

\section{Empirical literature on the factors influencing small, medium and micro-sized enterprises' borrowing from banks}

SMMEs struggle to get financing and they tend to get startup finance and working capital from informal sources such as founders' relatives and friends. Large enterprises on the other hand qualify for financing from formal institutions such as commercial banks and development banks (Abdesamed \& Wahab 2014; Okurut \& Ama 2013). This lack of financing, coupled with poor management of finances and other resources, has negatively affected growth and survival of SMMEs in Botswana.

The factors influencing SMME borrowing are mainly divided into firm characteristics and entrepreneurial characteristics. Various scholars have categorised firm characteristics into age, size, level of income, collateral, location, insurance, business information, industry type and registration (Berger \& Udell 1998; Fatoki \& Asah 2011).

Numerous scholars have postulated that entrepreneurial characteristics contribute to a firm's ability to obtain bank funding. They mention characteristics such as owners' character, managerial capabilities, networking abilities, gender, age, length of time in position, collateral, marital status and level of educational qualifications (Berger \& Udell 1998; Fatoki \& Asah 2011; Myers 1984). 
Considering most scholars' perspectives on factors influencing SMME borrowing (Berger \& Udell 2006; Chandler 2009; Fatoki 2013; Fatoki \& Asah 2011; Haron et al. 2013; Makhbul 2011; Mutoko \& Kapunda 2015; Myers 1984; Nguyen \& Luu 2013; Sidik 2012; Zarook, Rahman \& Khanam, 2013), the summary of main characteristics that influence borrowing include firm income (net profit or annual turnover) and owner's marital status, gender, highest education qualification and number of years in position.

Furthermore, Haron et al. (2013) found that management's character, collateral and borrowing capacity had a significant effect on the likelihood of loan approval by financial institutions. Contrarily, Abdesamed and Wahab (2014) unveiled that a firm's relationship with bankers and its business plan had a positive relationship with the firm's tendency to apply for loans. Thus, a small firm is more likely to apply for a loan as compared to a larger firm. A firm with a business plan is likely to apply for a loan.

In summary, factors that influence banks to lend money to SMMEs can be classified into entrepreneurial and firm factors. Following perusal of the various factors found in literature, this study applies both firm owner factors and firm factors through the multivariate logistic model (MLM) as follows: gender, number of years in position, marital status, highest level of formal education and annual sales turnover. These factors were chosen to bring together a mix of factors that cut across most studies in the discipline.

\section{Research method and design Research design}

The researcher employed both qualitative and quantitative designs, popularly known as multiple methods research design (triangulation) (Saunders, Lewis \& Thornhill 2012:161). Numerous researchers believe that triangulation is a good way of approaching research as it enables one to counteract the weaknesses in both qualitative and quantitative research (Bell 2010; Bell \& Waters 2014; Dawson 2009:20; Saunders et al. 2012:159-160; Trochim \& Donnelly 2008). By using the multiple methods research design, the researcher takes advantage of both numeric and non-numeric data, which helps them to conduct a more comprehensive analysis and thus enhance the data findings. This design is also beneficial in that it fulfils the expectations of both qualitative and quantitative readers and scholars.

\section{Sample and sampling technique}

This study adopted stratified random sampling because it reduces sampling error (Bell \& Water 2014). In this article, the researcher studied the manufacturing industry in Botswana. The strata are different districts in Botswana where the manufacturing industry is located. In this sampling technique, the researcher identified the relevant strata, namely, Gaborone Francistown, Maun, Serowe, Ghanzi and Kasane. In addition, random sampling with replacement was used to select a sufficient number of participants from each stratum, which is a reflection of the entire population of the manufacturing industry.

Furthermore, the stratified random sampling is divided into proportionate and disproportionate stratification. The formula is that the sample size of each stratum is proportionate to the population of the stratum. It implies that each stratum has the same sampling fraction. This provides more precision than simple random samples of the same size (Dawson 2009). Its gains in precision are even greater when studying the same phenomenon, in this case the manufacturing industry. In disproportionate stratification, the sampling fraction may vary from one stratum to another (Pfeffermann 1993). With this method, the researcher tends to maximize precision for a single important survey measure. Nevertheless, the gain in the precision may not accrue to other survey measures. The researcher adopted the proportionate stratification technique in order for the sample to reflect the entire opinion of the manufacturing industry and commercial banks in Botswana.

With proportionate stratification, the sample size of each stratum is proportionate to the population size of the stratum. Strata sample sizes are determined by the following equation: $n_{h}=\left(N_{h} / N\right) \times n$

$n_{h}$ is the sample size for stratum $h, N_{h}$ is the population size for stratum $h, N$ is total population size, and $n$ is total sample size. In this study, the appropriate sample size identified by the creative sample calculator is 100 . The outcome is presented in Table 3.

\section{Research instrument}

The data collection was conducted using three research approaches, namely documentary analysis, evidence and questionnaire. The researcher piloted the questionnaires before the main data collection among 12 manufacturing SMMEs to check the effectiveness and efficiency of the questionnaire. The pilot study was done in September 2014, followed by fine-tuning of the questionnaire according to feedback received from the SMME participants. The SMME participants in the pilot survey were left out of the main study to avoid repetition of findings. The data for the main study were collected between October 2014 and April 2015.

TABLE 3: Sampling for manufacturing small, medium and micro-sized enterprises.

\begin{tabular}{lcc}
\hline Districts & Registered SMMEs & Proportionate sample \\
\hline Gaborone & 185 & 56 \\
Francistown & 60 & 18 \\
Maun & 34 & 10 \\
Serowe & 25 & 8 \\
Ghanzi & 19 & 6 \\
Kasane & 6 & 2 \\
Total & 329 & 100 \\
\hline
\end{tabular}

SMME, small, medium and micro-sized enterprises. 


\section{Data analysis}

The current study used cross-sectional data, which consisted of both qualitative and quantitative data, which was captured, coded and analysed using the Statistical Package for Social Sciences (SPSS) computer software. All variables, including the response to the open-ended questions, closedended questions and interviews, were coded before being captured in SPSS (Martin \& Acuna 2002). Data were analysed using descriptive measures such as percentages, means, standard deviation and inferential statistics such as the t-test to test for differences in mean and logistic regression. Graphical and tabulation representations helped to further illustrate the results obtained. Thematic analysis of qualitative data was performed by classifying the data into themes, which were directed by the research hypotheses for establishment of articulated links between data and key patterns that emerged from the study (Hung \& Young 2015).

\section{Model specification and variables description}

There are different types of regression models, namely linear regression, logistic regression, polynomial regression, stepwise regression, ridge regression, lasso regression and elastic net regression ( $\mathrm{O}^{\prime}$ Gorman \& MacIntosh 2015). However, the type of regression model used is mostly dependent on the choice of the dependent variables. In this study, the logistic regression model is the appropriate model to apply in order to derive or obtain the factors that influence lending to manufacturing SMMEs, in other words, what lenders considered before lending to firms in order to hedge or minimise loan default (adverse selection). The study specified this model with five independent variables, which makes the logistic model a multivariate logistic regression model. The model is specified as:

$\log \left(\frac{p}{1-p}\right)=f\left(X_{1}, X_{2}, X_{3}, X_{4}, X_{5}\right)$

[Eqn 1]

Where, $\log \left(\frac{p}{1-p}\right)$ represents the log of probability of the respondent getting a loan $(p)$ while $1-p$ is the probability of not getting loan or applying for loan. It is also the dependent variable and a binary variable in which 1 denotes received or applied for loan and 0 denotes either as having not applied for any loan or having not received any loan. The $X$ variables are the independent or explanatory variables defined as follows:

$X_{1}$ is the gender of the respondents, which is a binary variable where 0 represents male and 1 represents female.

$X_{2}$ is the number of years the respondents have held their position, which is a binary variable in which 0 implies $0-10$ years and 1 means 11 years or more.

$X_{3}$ is the marital status of the respondents, in which 0 means not married and 1 means married.
The fourth explanatory variable $X_{4}$ is a binary variable in which 0 means 13 years of schooling or less and 1 means more than 13 years of schooling.

$X_{5}$ represents the business's annual turnover, which is captured as an ordered variable with three categories:.1 is P100 000 or less, 2 is P101 000-P400 000 and 3 is more than $\mathrm{P} 400000 . \mathrm{X}_{51}$ is 1 or 3 and $\mathrm{X}_{52}$ is 2 or 3 .

In summary equation (1) can be rewritten as:

$$
\begin{aligned}
\log \text { Loan }\left[\frac{\text { Have not borrowed }}{\text { Have borrowed }}\right]= & \beta_{0}+\beta_{1} X_{1}+\beta_{2} X_{2}+\beta_{3} X_{3}+ \\
& \beta_{4} X_{4}+\beta_{51} X_{51}+\beta_{52} X_{52}+\mu \quad \text { [Eqn 2] }
\end{aligned}
$$

The dependent variable is borrowing status, whether one has borrowed or not. Independent variables are annual income, education, number of years in position, marital status and gender.

$\beta_{0^{\prime}} \beta_{1^{\prime}}, \beta_{3^{\prime}} \beta_{4^{\prime}} \beta_{51}$ and $\beta_{52}$ are the parameters to be estimated and $\mu$ is an error term.

\section{Empirical results and discussion Demographic information of the manufacturing small, medium and micro-sized enterprises in Botswana}

Respondents from manufacturing SMMEs were asked to indicate their geographical location. From the sample of 100 SMMEs owners that responded to the questionnaire, the majority of respondents (72\%) are from Gaborone, 12\% are from Maun, 7\% in Francistown, 5\% in Kasane, 3\% in Serowe and $1 \%$ in Ghanzi. The results showed that $68 \%$ of manufacturing SMMEs are microenterprises, 20\% are small enterprises and $12 \%$ are medium enterprises.

Furthermore, respondents were asked to indicate how they obtained their initial finance (Figure 1).

Figure 1 shows that the majority of manufacturing SMMEs use their own money (79.0\%) to start and run their business. This supports the theory of internal financing where business owners do not borrow money when they start operating and they plough back profits for the business to progress as affirmed by Fatoki and Asah (2011) and World Population Review (2014). Manufacturing SMMEs have no choice, as they are small and usually do not have collateral security and premises; hence, they do not qualify for loans (external financing). $4.0 \%$ get their capital from family and friends, $3.0 \%$ of them from CEDA, $11.0 \%$ from government support, $2.0 \%$ from banks and $1.0 \%$ of them from micro lenders. With $11 \%$ getting grants and loans from government and $3 \%$ getting loans from CEDA (government funded agency), in total $14 \%$ receive financial support from government. The government and financial institutions therefore need to finance more manufacturing SMMEs to increase chances of survival. The result demonstrates that manufacturing SMMEs mostly engage the internal funds theory, which 


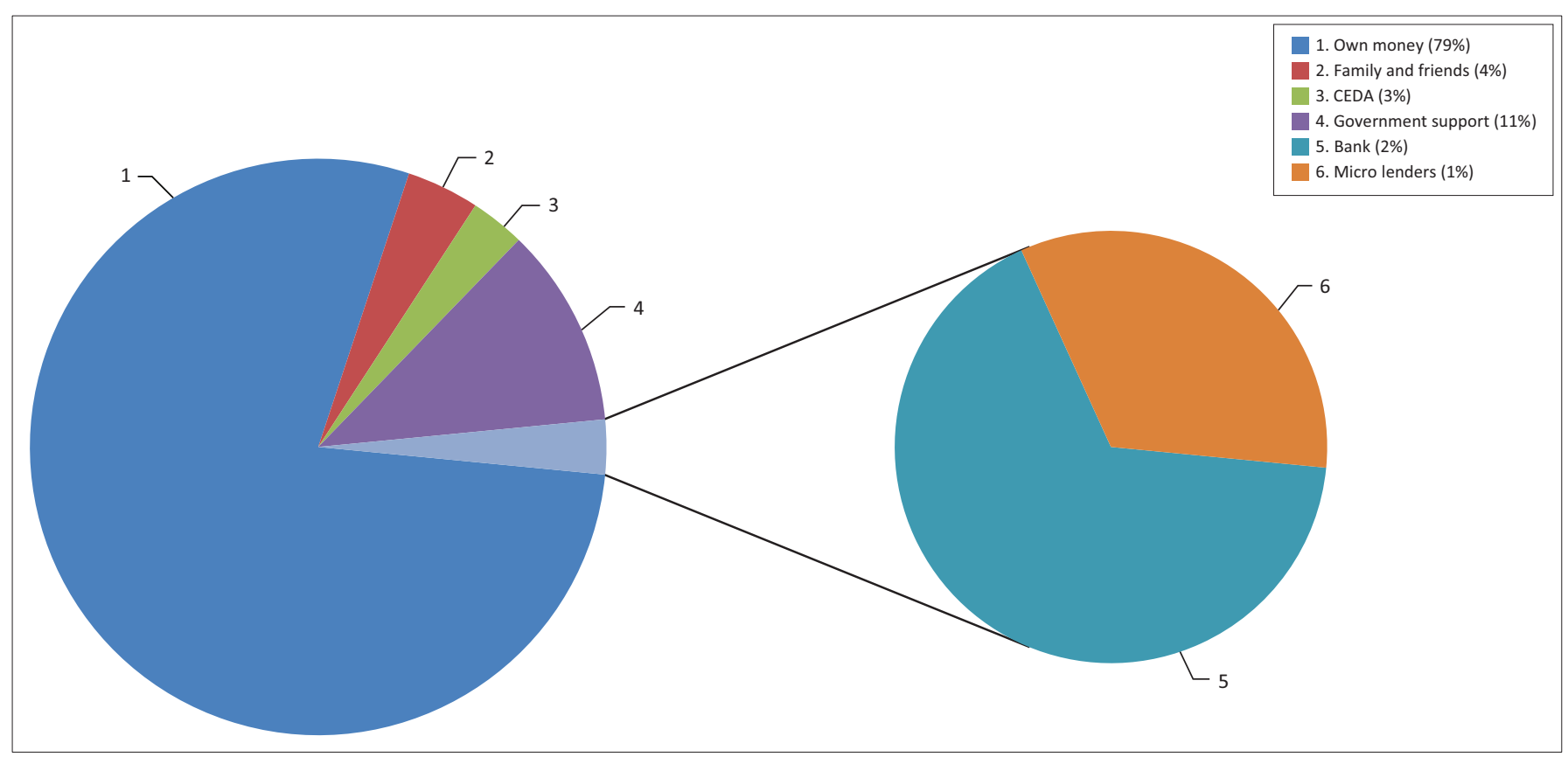

Source: Research findings 2015

FIGURE 1: How small, medium and micro-sized enterprises initially financed their business $(\mathrm{N}=98)$.

TABLE 4a: Variables used in the multivariate regression analysis.

\begin{tabular}{lll}
\hline Case summary & $N$ & Marginal percentage \\
\hline $\begin{array}{l}\text { Have you taken a loan before? } \\
\text { Have not borrowed }\end{array}$ & 39 & 58.2 \\
$\quad$ Borrowed & 28 & 41.8 \\
Gender & & \\
$\quad$ Male & 49 & 73.1 \\
$\quad$ Female & 18 & 26.9 \\
Number of years in position & & \\
0-10 & 53 & 79.1 \\
11 and above & 14 & 20.9 \\
Marital status & & \\
$\quad$ Not married & 29 & 43.3 \\
$\quad$ Married & 38 & 56.7 \\
Highest level of formal education of the owner & & \\
$\quad \leq 13$ years of schooling & 21 & 31.3 \\
$>13$ years of schooling & 46 & 68.7 \\
Annual turnover & & \\
$\quad \leq$ P100 000 & 34 & 50.7 \\
P101 000-P400 000 & 17 & 25.4 \\
$>$ P400 000 & 16 & 23.9 \\
Valid & 67 & 100 \\
Not indicated & 33 & - \\
\hline Total & 100 & \\
\hline
\end{tabular}

Source: Research findings 2015

$N$, number.

suggests that firms use their own funds, and retained profits to finance the business rather than borrow (external funds theory).

\section{Factors that influence manufacturing small, medium and micro-sized enterprises' borrowing}

To derive sufficient meaning from factors influencing manufacturing SMMEs' borrowing, multivariate logistic regression analysis is used in this paper as illustrated in Table $4 \mathrm{a}$, Table $4 \mathrm{~b}$ and Table 5.

\section{Multivariate logistic regression results}

Ho1: Factors influencing SMME borrowing include firm income (net profit or annual turnover), marital status, gender, highest education qualification and number of years in position.

Table $4 \mathrm{a}$ and Table $4 \mathrm{~b}$ shows the case summary of the variables used in the multivariate regression analysis, model fitting criteria and pseudo R-square. The variables used in the model are loan variable, which is captured as 'not borrowed' as the reference category and 'borrowed' is the base and dependent variable. The independent variables include gender, marital status, annual turnover, highest education qualification and number of years in position. The pseudo R-square shows from the Nagelkerke statistic, which is the same as R-square in a time series analysis showing that the explanatory variables explain $37.6 \%$ variation in the explained variable.

The result of the multivariate logistic regression in Table 5 shows that an increase in married people participating in loan applications by a unit reduces the odds of not married people receiving a loan by 1.223 units. The result is statistically significant at $1.0 \%$. This implies that as the number of married people's applications for a loan increases, the rate at which the number of unmarried people receiving a loan for their businesses will reduce by 1.233 units. It also means that lenders see marriage as a sign of responsibility and as such, it is an obligation for the couple to make sure their loans are paid in order not to be blacklisted in all financial matters. Furthermore, in Botswana, lenders, and especially organised financial institutions, permit both partners to sign jointly for a loan before being approved. 
TABLE 4b: Variables used in the multivariate regression analysis.

\begin{tabular}{|c|c|c|c|c|c|c|}
\hline \multirow[t]{2}{*}{ Effect } & \multicolumn{3}{|c|}{ Model fitting criteria } & \multicolumn{3}{|c|}{ Likelihood ratio tests } \\
\hline & $\begin{array}{l}\text { AIC of reduced } \\
\text { model }\end{array}$ & $\begin{array}{l}\text { BIC of reduced } \\
\text { model }\end{array}$ & $\begin{array}{l}-2 \text { log likelihood of } \\
\text { reduced model }\end{array}$ & Chi-square & df & Sig. \\
\hline Intercept & 50.820 & 66.252 & $36.820^{\mathrm{a}}$ & 0.000 & 0 & \\
\hline Gender & 48.862 & 62.090 & 36.862 & 0.0420 & 1 & 0.837 \\
\hline Years in position & 55.322 & 68.550 & 43.322 & 6.502 & 1 & 0.011 \\
\hline Marital status & 59.654 & 72.883 & 47.654 & 10.835 & 1 & 0.001 \\
\hline Highest level of formal education of the owner & 51.674 & 64.902 & 39.674 & 2.854 & 1 & 0.091 \\
\hline Annual turnover & 53.518 & 64.541 & 43.518 & 6.698 & 2 & 0.035 \\
\hline \multicolumn{7}{|l|}{ Pseudo R-square } \\
\hline Cox and Snell & \multicolumn{6}{|c|}{0.280} \\
\hline Nagelkerke & \multicolumn{6}{|c|}{0.376} \\
\hline McFadden & \multicolumn{6}{|c|}{0.241} \\
\hline \multicolumn{7}{|l|}{$\begin{array}{l}\text { Source: Research findings } 2015 \\
\text { AIC, Akaike's information criterion; BIC, }\end{array}$} \\
\hline Have you taken loan before? & B & Standard. error & Wald & df & Sig. & $\operatorname{Exp}(B)$ \\
\hline Intercept & -2.001 & 1.110 & 3.248 & 1 & 0.072 & - \\
\hline \multicolumn{7}{|l|}{ Gender } \\
\hline Male & 0.157 & 0.761 & 0.042 & 1 & 0.837 & 1.170 \\
\hline Female & $0^{\mathrm{a}}$ & - & - & 0 & - & - \\
\hline \multicolumn{7}{|l|}{ Number of years in position } \\
\hline $1-10$ & 1.954 & 0.810 & 5.813 & 1 & 0.016 & 7.057 \\
\hline $11-50$ & $0^{\mathrm{a}}$ & - & - & 0 & - & - \\
\hline \multicolumn{7}{|l|}{ Marital status } \\
\hline Not married & -2.233 & 0.761 & 8.617 & 1 & 0.003 & 0.107 \\
\hline Married & $0^{\mathrm{a}}$ & - & - & 0 & - & - \\
\hline \multicolumn{7}{|l|}{ Highest level of formal education of the owner } \\
\hline$\leq 13$ years of schooling & 1.128 & 0.689 & 2.677 & 1 & 0.102 & 3.089 \\
\hline$>13$ years of schooling & $0^{\mathrm{a}}$ & - & - & 0 & - & - \\
\hline$\leq \mathrm{P} 100000$ & 1.969 & 0.835 & 5.554 & 1 & 0.018 & 7.160 \\
\hline P101 000-P400 000 & 1.630 & 0.907 & 3.231 & 1 & 0.072 & 5.105 \\
\hline > P400 000 & $0^{\mathrm{a}}$ & - & - & 0 & - & - \\
\hline
\end{tabular}

Source: Research findings 2015

The variables used in the model are loan variable, which is captured as 'not borrowed'.

B, regression beta coefficient; Wald, Wald Chi-Squared Test; df, degrees of freedom; Sig., significance; Exp(B), exponentiation of the B coefficient.

a, The reference category is: 'Borrowed'.

The model shows that the variables identified as the factors that influence banks' lending to SMMEs support the credit rationing theory. This is shown by the negative significant impact of the intercept on the dependent variable. It implies that in the absence of any explanatory variables, there is reduction in the odds of businesses not borrowing by $2.0 \%$. This is because banks do not lend or give out loans without understanding their clients. It then means that if a manufacturing SMME wants to borrow money from the bank, they should have good financial records, experienced management and a good home.

The result also shows that an increase in turnover by a unit will increase the odds of a business with a turnover between P101 000 and P400 000 getting the loan by 0.630 units more as compared to those with an annual turnover of over P400 000. This effect is statistically significant at $10.0 \%$. Furthermore, a unit increase in the turnover of business raises the odds of a business with an annual turnover of P100 000 or less by 0.969 units more as compared to those with a turnover of P400 000 or more. It implies therefore, that applicants with higher turnover are more likely to get a loan as compared with those with lower sales turnover. This result is consistent with Haron et al.'s (2013) study in Malaysia and with Okurut et al. (2011). It also means that banks use a firm's financial records to assess the ability of the firm to pay back a loan.

In addition, the result shows that female SMME owners are more likely to get loans compared to their male counterparts in Botswana. Women in Botswana are regarded as responsible. That is why generally in schools girls perform better than boys. In positions of power in the corporate world, there are many women at the top. Most homes have women as breadwinners. Historically, women have been known to be more loyal than men. Based on these observations, it can be understood why women in Botswana would be more likely to get loans than men. The other reason that influences married people obtaining loans more than unmarried SMME owners is to do with the cost involved in defaulting. When couples default, they will be blacklisted in all the financial institutions in Botswana as bad borrowers. This also affects any activities in the future that involve trust. 
Furthermore, an increase in an SMME owner's educational level increases the odds SMME owners with an education level up to 13 years of schooling by 0.128 units more than those with more than 13 years of schooling. These effects, however, are statistically insignificant. This implies that the factor of the owner's educational level does not necessarily help to increase their chances of obtaining a loan among manufacturing SMMEs in Botswana, according to the sample. Nonetheless, Abdesamed and Wahab (2014) showed that education has negative effect on Libyan firms trying to obtain loans from banks.

The results also show that an increase in the number of years that the SMME owner, director or manager has held their position increases the odds of not getting a loan for those who have been in the position between 1 and 10 years as compared to those who have been in the position for more than 10 years by 0.954 . This effect is statistically significant. This implies that banks are more likely to grant a loan to an SMME owner, director or manager that has been in their position longer as opposed to those who have just assumed the position. Similarly, Okurut et al. (2011) and Abdesamed and Wahab (2014) showed that the experience of the owner increases the likelihood of a bank lending to an SMMEs as compared to management with less experience.

\section{Conclusions and recommendations}

The results show that most of the manufacturing SMMEs started their businesses with their own money and such should be a sign that there is hope for expansion. However, given that banks are not governmental organisations but are profit-making entities, credit rationing plays a significant role in lending. The major hindrance for an SMME's growth is lack of finance and related factors. The factors that influence banks to lend SMMEs money include the marital status and experience of the management and annual turnover. The article recommends that manufacturing SMMEs should focus more on marketing, networking and the ability to manage their resources efficiently. Since SMMEs are struggling with accounting records, shortage of skills and scarce resources, they should engage in regular formal and informal training to keep abreast with the changing business environment so they can remain relevant. The formal training can include sending management and staff on refresher courses, workshops, seminars and short courses. Informal training can include personal development encouraged by having a company library, which helps staff and management to study and remain open-minded and stay abreast of changes in the industry. One form of training should be acquisition of money management skills such as finance for non-finance managers, which is offered by local institutions such as Botswana Accountancy College and BAISAGO University.

\section{Acknowledgements}

Special thanks to North-West University (Mafikeng campus), to my supervisor Prof. Kapunda and to research participants.

\section{Competing interests}

Authors declare that they have no financial or personal relationship(s) that may have inappropriately influenced them in writing this article.

\section{Authors' contributions}

W.R.M. contributed to the research and writing of this article as supervisee under the guidance of S.M.K.

\section{References}

Abdesamed, K.H. \& Wahab, K.A., 2014, 'Financing of small and medium enterprises: Determinants of bank loan application', African Journal of Business Management 8(17), 717-727. https://doi.org/10.5897/AJBM2013.7222

Abor, J.Y., Agbloyor, E.K. \& Kuipo, R., 2014, 'Bank finance and export activities of small and medium enterprises', Review of Development Finance (4), 97-103.

Andrae, G. \& Beckman, B., 2013, 'Lagos tailors, trade unions, and organizations in the informal economy', African Studies Review 56(3), 191-208. https://doi.org/10. 1017/asr.2013.85

Baliyan, S.P., 2013, 'Institutions and organisations contributing to entrepreneurship education and skill development in Botswana', Journal of Sustainable Development in Africa 15(5), 1-6.

Bell, J., 2010, Doing your research project: A guide for first-time researchers in education, health and social science, 5th edn., Open University Press, London, England.

Bell, J. \& Waters, S., 2014, Doing your research project: A guide for first-time researchers in education, health and social science, 2 nd edn., Open University Press, London, England.

Berger, A.N. \& Udell, G.F., 1998, 'The economics of small business finance: The roles of private equity and debt markets in the financial growth cycle', Journal of Banking \& Finance 22(6-8), 613-673. https://doi.org/10.1016/S03784266(98)00038-7

Berger, A.N. \& Udell, G.F., 2006, 'A more complete conceptual framework for SME finance', Journal of Banking \& Finance, 30(11), 2945-2966.

Bester, H., 1987, 'The role of collateral in credit markets with imperfect information', European Economic Review 31(4), 887-899. https://doi.org/10.1016/0014-2921 (87)90005-5

BIDPA, 2009, Performance and competitiveness of small and medium sized manufacturing enterprises in Botswana, viewed 04 July 2014, from http://bidpa. co.bw

Botswana Central Statistics Office, 2015, 'Gross domestic product second quarter of 2015', viewed 08 April 2016, from http://www.cso.gov.bw/images/gdp_Q2.pdf

Chandler, A.D., 2009, Shaping the industrial century: The remarkable story of the evolution of the modern chemical and pharmaceutical industries, vol. 46, Harvard University Press, Cambridge, MA.

Dawson, C., 2009, Introduction to research methods. A practical guide for anyone undertaking a research project, 4th edn., How to Books Ltd, London, England.

Fatoki, O., 2013, 'The determinants of longevity of micro enterprises in South Africa', Journal of Economics 4(2), 133-143.

Fatoki, O. \& Asah, F., 2011, 'The impact of firm and entrepreneurial characteristics on access to debt finance by SMEs in King Williams' Town, South Africa', Internationa Journal of Business and Management 6(8),170-179. https://doi.org/10.5539/ ijbm.v6n8p170

Ghimire, B. \& Abo, R., 2013, 'An empirical investigation of Ivorian SMEs access to bank finance: Constraining factors at demand-level', Journal of Finance and Investment Analysis 2(4), 29-55.

Gichuki, J.A.W., Njeru, A. \& Tirimba, O.I., 2014, 'Challenges facing micro and small enterprises in accessing credit facilities in Kangemi Harambee market in Nairob City County, Kenya', International Journal of Scientific and Research Publications 4(12), 1-25.

Haron, H., Said, S.B., Jayaraman, K. \& Ismail, I., 2013, 'Factors influencing small medium enterprises (SMES) in obtaining loan', International Journal of Business and Social Science 4(15), 182-195, (Special Issue - November 2013).

Harris, M. \& Raviv, A., 1990, 'Capital structure and the informational role of debt', Journal of Finance 45(1), 321-349. https://doi.org/10.1111/j.1540-6261.1990. tb03693.x

Hillbom, E., 2012, 'Botswana: A development-oriented gate-keeping state', Oxford Journals, Social Sciences, African Affairs 111(442), 67-89. https://doi.org/10.1093/ afraf/adr070

Huang, C., When, Y. \& Liu, Z., 2014, 'Analysis on financing difficulties for SMEs due to asymmetric information', Global Disclosure of Economics and Business 3(2), 28-31.

Hung, H. \& Young, S.S., 2015, 'The effectiveness of adopting e-readers to facilitate EFL students' process-based academic writing', Educational Technology \& Society $18(1), 250-263$.

Jefferis, K., 2014, The new policy on small, medium \& micro enterprises, viewed 11 February 2014, from http://www.bidpa.bw 
Lapar, M.L.A. \& Graham, D.H., 1988, Credit rationing under a deregulated financial system, Working Paper Series No. 88-19, Philippine Institute for Development system, Working Paper Series
Studies, Makati City, Philippines.

Makhbul, Z.M., 2011, 'Entrepreneurial success: An exploratory study among entrepreneurs', International Journal of Business and Management 6(1), 116-125.

Martin, K. \& Acuna, C., 2002, SPSS for institutional researchers, Bucknel University Press, Lewisburg, PA

Mazanai, M. \& Fatoki, O., 2012, 'Access to finance in the SME sector: A South African perspective', Asian Journal of Business Management 4(1), 58-67.

Messah, O.B. \& Wangai, P.N., 2011, 'Factors that influence the demand for credit for credit among small scale investors: A case study of Meru Central District, Kenya', Research Journal of Finance and Accounting 2(2), 1-23.

Modigliani, F. \& Miller, M.H., 1963, 'Corporate income taxes and the cost of capital - A correction', American Economic Review 53(3), 433-443.

Moore, C.W., Petty, J.W., Palich, L.E. \& Longenecker, J.G., 2010, Managing small business: An entrepreneurial emphasis, 15th edn., International Edition, South Western Cengage Learning, New Delhi, India.

Mutambi, J., 2013, Stimulating industrial development in Uganda through open innovation business incubators, viewed 10 March 2016, from http://www.divaportal.org/smash/record.jsf?pid=diva2\%3A834399\&dswid=6748.

Mutoko, R.W., 2014, 'Challenges of access to markets and opportunities for small, medium, and micro enterprises (SMMEs) in Botswana', European Scientific Journal 2(2), 28-38.

Mutoko, R.W. \& Kapunda, S.M., 2015, 'Characteristics of successful small, micro, and medium enterprise owners: The case of Botswana manufacturing sector', in 3rd Biennial Africa Academy of Management (AFAM) Conference, Nairobi, Kenya, January 5-10, 2016.

Mutoko, R.W., Mokone, W.S. \& Thindwa, K., 2015, 'The complexities of relationships between small and medium enterprises (SMEs) and commercial banks - The case of Botswana's retail SMEs', in International Conference on Transforming and Growing Economies through Sustainable Business Innovation, University of Botswana, Maun, Botswana, viewed 10 March 2016, from https://mail.google. $\mathrm{com} / \mathrm{mail} / \mathrm{u} / 0 /$ \#search/ub/14ede68c00dc20aa?projector=1

Myers, S.C., 1984, 'The capital structure puzzle', Journal of Finance 39(3), 575-592. https://doi.org/10.2307/2327916.

Nguyen, N. \& Luu, N., 2013, 'Determinants of financing pattern and access to formalinformal credit: The case of small and medium sized enterprises in Vietnam' Journal of Management Research 5(2), 240-259. https://doi.org/10.5296/jmr. v5i2.3266

Nuryartono, N., Stefan, S. \& Manfred, Z., 2005, 'Credit rationing of farm households and agricultural production: Empirical evidence in the rural areas of Central Sulawesi Province, Indonesia', in Conference on International Agricultural Research for Development, Deutscher Tropentag, October 11-13, 2005, Hohenheim.

O'Gorman, K. \& MacIntosh, R., 2015, Research methods for business and management-A guide to writing your dissertation, 2nd edn., Goodfellow Publishers Ltd, London
Okurut, F.N. \& Ama, N.O., 2013, 'Assessing factors that affect women and youth microentrepreneurs in Botswana', International Journal of Academic Research in Economics and Management Sciences 2(1), 306-332.

Okurut, F.N., Olalekan, Y. \& Mangadi, K., 2011, 'Credit rationing and SME development in Botswana: Implications for economic diversification', Botswana Journal of Economics 8(12), 62-85.

Padilla-Perez, R. \& Ontañon, R.F., 2013, 'Commercial bank financing for micro enterprises and SMEs in Mexico', Cepal Review 111, viewed 23 December 2013 from http://repositorio.cepal.org/bitstream/handle/11362/37002/RVI111Padilla Fenton_en.pdf?sequence $=1$

Pfeffermann, D., 1993, 'The role of sampling weighs when modeling survey data', International Statistical Review 61(2), 317-337.

Rhodes, C., 2012, Small medium and micro enterprises, House of Commons Library, Standard Note: SN/EP/6078, London, England.

Rothschild, M. \& Stiglitz, J., 1971, 'Increasing risk: A definition', Journal of Economic Theory 2(3), 225-243. https://doi.org/10.1016/0022-0531(70)90038-4

Saunders, M., Lewis, P. \& Thornhill, A., 2012, Research methods for business student, 6th edn., Prentice Hall, Essex.

Sekwati, L., 2010, 'Botswana: A note on economic diversification', viewed 7 July 2014, from www.ajol.info/index.php/boje/article/download/64205/52000

Senior, A., 2012, 'Financing the micro, small and medium enterprises (MSMEs) sector in Jamaica: Constraints and prospects for leasing, factoring and microfinance', viewed 23 March 2016, from http://boj.org.jm/uploads/pdf/ papers pamphlets/papers pamphlets Financiang the MSME Sector in Jamaica_Constraints_and_Prospects_for_Leasing,_Factoring_and_ Microfinance.pdf

Shemi, A.P., 2013, 'Challenges of e-commerce adoption in SMEs: An interpretive case study of Botswana', Botswana Journal of Business 6(1), 17-30.

Sidik, I. G., 2012, 'Conceptual framework of factors affecting SME development: Mediating factors on the relationship of entrepreneur traits and SME performance', Procedia Economics and Finance 4, 373-383. https://doi.org/10. 1016/S2212-5671(12)00351-6

Stiglitz, J. \& Weis, A., 1981, 'Credit rationing in markets with imperfect information', The American Economic Review 71(3), 393-410.

Trochim, W.M.K. \& Donnelly, J.P., 2008, The research methods knowledge base, 3rd edn., Cengage Learning, Mason, $\mathrm{OH}$.

Wiklund, J. \& Shepherd, D., 2005, 'Entrepreneurial orientation and small business performance: A configurational approach', Journal of Business Venturin, 20 , performan.

World Population Review, 2014, Population of Botswana, viewed 14 June 2014, from http://worldpopulationreview.com/countries/botswana-population/

Zarook, T., Rahman, M.M. \& Khanam, R., 2013, 'The impact of demographic factors on accessing finance in Libya's SMEs', International Journal of Business and Management, 8(14), 55. 